\title{
Hubungan Penggunaan Model Pembelajaran Langsung Dengan Sikap Siswa dan Prestasi Belajar Siswa pada Materi Larutan Elektrolit dan Nonelektrolit
}

\author{
Karmila Bella ${ }^{* a}$, Wilson A. R, Rombang ${ }^{a}$, Meiske N. Mamuaja ${ }^{a}$ \\ a Universitas Negeri Manado, Minahasa, 95618, Indonesia
}

INFO ARTIKEL

Diterima 13 November 2019

Disetujui 31 Desember 2019

Key word:

Direct Instruction

Learning Achievement

Student Attitude

Electrolyte and nonelectrolyte

\section{Kata kunci:}

Pembelajaran Langsung

Prestasi Belajar

Sikap Siswa

Larutan Elektrolit dan

Nonelktrolit

\section{A BSTRACT}

A direct instruction model research been conducted on student of SMA N 2 Tondano in second semester of the 2018/2019 school year. This study aims to determine the relationship of direct instruction models with student anttitudes and increase student achievement in electrolyte and nonelectrolyte solution material. This study use experimental method with one group pretest-posttest design. The population in this study were student of class X IPA at SMA N 2 Tondano. Testing the validity of the question instrument obtained 10 valid question and 2 invalid question, while the reliability test of the question instrument obtained a reliability coefficient of 0.785 . Testing the distribution of positive attitudes of student before and after treatment result. Based on the result of the percentage difference above shows that student attitudes and student achievement have or increased. The results of normality tests showed Lcount $<$ Lable for the experimental class $(0.10<0.17)$ so that the data were normally distributed. Then the hypothesis test can be done using the Pearson Product Moment correlation test obtained $r_{x y}$ value $=0.602$, then the test significant correlation value $r$ into the $t$ value with the test criteria $t_{\text {count }}>t$ table. From the calculation that tount (3.62) $>t_{\text {table }}$ (2.06). This study concludes that there is a relationship between the direct instruction model with student attitudes and student achievement on electrolyte and nonelectrolyte solution material.

\section{A BSTRAK}

Telah dilakukan penelitian model pembelajaran langsung pada siswa SMA Negeri 2 Tondano di semester genap tahun ajaran 2018/2019. Penelitian ini bertujuan untuk mengetahui hubungan model pembelajaran langsung dengan sikap siswa dan peningkatan prestasi belajar siswa pada materi larutan elektrolit dan nonelektrolit. Penelitian ini menggunakan metode eksperimen dengan desain penelitian one group pretest-posttest design. Populasi dalam penelitian ini adalah siswa kelas X IPA SMA Negeri 2 Tondano. Pengujian validitas instrumen soal diperoleh 10 soal yang valid dan 2 soal tidak valid, sedangkan pengujian reliabilitas instrumen soal diperoleh koefisien reliabilitas 0,785 . Pengujian distribusi sikap positif siswa sebelum dan sesudah perlakuan diperoleh hasil bahwa sikap positif siswa tentang pembelajaran kimia meningkat. Berdasarkan hasil presentase selisih diatas menunjukkan bahwa sikap siswa dan prestasi belajar siswa mengalami kenaikan atau peningkatan.Hasil uji normalitas menunjukkan Lhitung $<$ Ltabel untuk kelas eksperimen $(0,10<0,17)$ sehingga data berdistribusi normal. Maka dapat dilakukan uji hipotesis menggunakan uji korelasi Pearson Product Moment diperoleh nilai $\mathrm{r}_{\mathrm{xy}}=0,602$, selanjutnya uji signifikan nilai korelasi $\mathrm{r}$ kedalam nilai t dengan kriteria pengujian thitung $>$ ttabel. Dari hasil perhitungan bahwa thitung (3.62) ttabel $(2,06)$. Penelitian ini menyimpulkan bahwa terdapat hubungan antara model pembelajaran langsung dengan sikap siswa dan prestasi belajar siswa pada materi larutan elektrolit dan nonelektrolit. 


\section{Pendahuluan}

Prestasi belajar rendah adalah sebagai kegagalan dalam sistem pendidikan dan pembelajaran. Sekitar $20 \%$ anak-anak tidak mencapai prestasi yang memadai pada sekolah lanjutan atas serta tidak mencapai tingkat prestasi yang memadai dalam sains, matematika dan membaca [1]. Prestasi belajar rendah dalam kimia lebih banyak ditentukan oleh siswa yang memiliki kesulitan belajar. Hal ini menyebabkan siswa tidak memiliki cukup banyak ilmu pengetahuan untuk meningkatkan prestasi belajar mereka [2].

Sikap terhadap suatu mata pelajaran memiliki pengaruh pada prestasi belajar. Sikap positif terhadap mata pelajaran kimia membuktikan bahwa prestasi siswa menjadi lebih baik dalam mata pelajaran kimia. Prestasi dan sikap dapat ditingkatkan oleh siswa dengan metode pembelajaran kimia dan lingkungan belajar yang lebih menyenangkan. Siswa yang memiliki sikap positif berdampak penting untuk dapat memahami pelajaran di kelas, karena sikap cenderung menurun seiring waktu [3]. Untuk meningkatkan prestasi belajar siswa yang rendah dalam bidang kimia, diperlukan lebih banyak penelitian untuk memahami sikap dan model pembelajaran yang sesuai untuk siswa. Salah satu tantangan terbesar bagi guru adalah untuk mengetahui sikap siswa dalam kelas dan guru harus dapat menyesuaikan dan mengembangkan metode pembelajaran yang sesuai dengan kebutuhan siswa [4].

Sikap positif terhadap kimia berkorelasi dengan prestasi belajar. Penelitian lainnya menyatakan bahwa siswa laki-laki menunjukkan sikap yang lebih positif terhadap pembelajaran kimia dibandingkan dengan siswa perempuan. Dengan demikian bahwa menggunakan model pembelajaran yang disukai siswa merupakan hal penting untuk meningkatkan prestasi belajar. Salah satu model pembelajaran yang dapat meningkatkan prestasi belajar siswa dan memperbaiki sikap siswa terhadap pembelajaran kimia adalah model pembelajaran langsung [5].

Model pembelajaran langsung merupakan salah satu model pembelajaran yang dirancang khusus untuk mengembangkan belajar siswa tentang pengetahuan prosedural dan pengetahuan deklaratif yang terstruktur dengan baik dan dapat dipelajari langkah demi langkah. Model pembelajaran Langsung memiliki banyak kelebihan yang diantaranya guru mengendalikan isi materi dan urutan informasi yang diterima oleh siswa sehingga dapat mempertahankan fokus mengenai apa yang harus dicapai oleh siswa. Model pembelajaran langsung membuat pelajaran menjadi lebih efektif dikarenakan guru akan lebih banyak menggunakan waktu untuk mendemonstrasikan dan menjelaskan prosedur-prosedur dan keterampilan materi [6].

Penelitian ini bertujuan mengetahui hubungan antara model pembelajaran langsung dengan sikap siswadan prestasi belajar siswa pada materi larutan elektrolit dan nonelktrolit.

\section{Metode}

Penelitian ini dilaksanakan di SMA N 2 Tondano pada semester genap tahun ajaran 2018/2019 pada materi larutan elektrolit dan nonelektrolit. Peneliti menggunakan model pembelajaran langsung.

Desain penelitian ini menggunakan desain one group pretest-posttest desaign [7]. Adapun Desain penelitiannya dapat dilihat pada tabel 1 berikut:

Tabel 1. Desain Penelitian

\begin{tabular}{lccc}
\hline Kelompok & $\begin{array}{c}\text { Prete } \\
\text { st }\end{array}$ & $\begin{array}{c}\text { Treatmen } \\
\boldsymbol{t}\end{array}$ & $\begin{array}{c}\text { Posttes } \\
\boldsymbol{t}\end{array}$ \\
\hline Eksperimen & $\mathrm{O}_{1}$ & $\mathrm{X}$ & $\mathrm{O}_{2}$ \\
\hline $\mathrm{O}_{1}=$ Nilai pretest (sebelum pembelajaran) \\
$\mathrm{X}=$ Perlakuan (Treatment) \\
$\mathrm{O}_{2}=$ Nilai Posttest (setelah pembelajaran)
\end{tabular}

\section{Hasil dan Pembahasan}

Hasil Penelitian

Data hasil penelitian diambil menggunakan soal tes hasil belajar. Untuk soal tes tersebut telah diuji validitas dan reliabilitas sebelum digunakan dalam pengujian validitas dan reliabilitas melibatkan responden sebanyak 17 siswa di kelas XII IPA, sedangkan pada pengujian prasyarat analisis data melibatkan responden sebanyak 25 siswa di kelas X IPA sebagai kelas eksperimen di SMA Negeri 2 Tondano.

Data penelitian ini diperoleh dari satu 
kelas eksperimen di SMA Negeri 2 Tondano yaitu kelas X IPA yang diterapkan model pembelajaran langsung semester genap tahun ajaran 2018/2019 dengan jumlah 25 siswa. Data selanjutnya digunakan untuk mengetahui hubungan model pembelajaran langsung terhadap sikap siswa. Untuk data sikap peneliti mempersiapkan angket yang terdiri dari 20 item pernyataan yang terbagi dalam dua bagian yaitu pernyataan positif dan pernyataan negatif. Kisi-kisi angket dibuat berdasarkan sikap atau minat siswa terhadap pembelajaran kimia serta ketertarikan siswa terhadap model pembelajaran langsung. Angket diberikan sebelum dan sesudah perlakuan. Data prestasi belajar siswa yang didapat dari hasil tes awal dan tes akhir berupa soal essay 10 butir (pretest dan posttest). Untuk memastikan kesahihan soal yang diberikan dilakukan uji validitas dan uji reliabilitas butir soal.

Data hasil uji pada tabel 2 dan tabel 3 menunjukkan bahwa skor rata-rata angket siswa yang menyukai kimia sebelum diberikan model pembelajaran langsung adalah 60,92 dan sesudah diperoleh 90,08. Dimana skor rata-rata dari prestasi belajarnya pada pretest 57,96 dan posttest adalah 89,36.

Berdasarkan data tabel 2 terlihat bahwa skor rata-rata siswa yang menyukai kimia sebelum diberikan model pembelajaran langsung adalah 60,92 dan sesudah perlakuan diperoleh 90,08 atau naik sejumlah 47,86\%. Selanjutnya berdasarkan data tabel 3 terlihat bahwa skor rata-rata prestasi siswa sebelum diberikan model pembelajaran langsung (pretest) adalah 57,96 dan sesudah perlakuan (posttest) diperoleh 89,36 atau naik sejumlah $54,17 \%$.

Tabel 2. Data angket sebelum dan sesudah perlakuan

\begin{tabular}{|c|c|c|c|}
\hline \multirow[b]{2}{*}{ No } & \multirow[b]{2}{*}{ Data Statistika } & \multicolumn{2}{|c|}{ Nilai Statistika } \\
\hline & & $\begin{array}{l}\text { Angket } \\
\text { Sebelum }\end{array}$ & $\begin{array}{l}\text { Angket } \\
\text { Sesudah }\end{array}$ \\
\hline 1 & Skor Minimum & 29 & 76 \\
\hline 2 & $\begin{array}{c}\text { Skor } \\
\text { Maksimum }\end{array}$ & 79 & 98 \\
\hline 3 & Total Skor & 1523 & 2252 \\
\hline 4 & Rata-rata & 60,92 & 90,08 \\
\hline 5 & $\begin{array}{c}\text { Simpangan } \\
\text { Baku }\end{array}$ & 14,96 & 6,95 \\
\hline
\end{tabular}

Tabel 3. Data pretest dan posttest

\begin{tabular}{cccc}
\hline \multirow{2}{*}{ No } & Data Statistika & \multicolumn{2}{c}{ Nilai Statistika } \\
\cline { 3 - 4 } 1 & Sketest & Posttest \\
& Skor & 43 & 80 \\
& Minimum & & \\
2 & Skor & 78 & 97 \\
3 & Maksimum & & 2234 \\
4 & Total Skor & 1449 & 89,36 \\
5 & Rata-rata & 57,96 & 5,44 \\
\hline
\end{tabular}

1. Instument Penelitian

a. Validitas

Uji validitas item soal dihitung dengan menggunakan korelasi product moment dengan bantuan program MS Excel, dengan taraf signifikansi 0,05 dan $\mathrm{N}=17$ didapatkan rtabel $=$ 0,48 . Hasil dari perhitungan koefisien korelasi product moment (rhitung) kemudian dibandingkan dengan rtabel, jika nilai rhitung tiap item soal kurang dari rtabel dinyatakan tidak valid dan jika rhitung tiap item soal lebih dari rabel dinyatakan valid.

\section{b. Reliabilitas}

Pengujian reliabilitas dilakukan dengan tujuan untuk memastikan soal yang akan diberikan ke kelas eksperimen layak digunakan atau tidak. Koefisien reliabilitas item soal didapat dengan menggunakan rumus KR.20, sebagai berikut:

$$
r_{11}=\left(\frac{k}{(k-1)}\right)\left(1-\frac{\Sigma \sigma_{b}{ }^{2}}{\sigma_{1}{ }^{2}}\right)
$$

Hasil perhitungan uji reliabilitas item soal diperoleh $\mathrm{r}_{11}=0,78$, sehingga dapat dikatakan bahwa item soal memiliki kriteria reliabilitas tinggi. Kriteria yang digunakan sebagai berikut:

Tabel 4. Kategori koefisien reliabilitas

\begin{tabular}{ll}
\hline Rentang nilai $\mathrm{r}_{11}$ & \multicolumn{1}{c}{ Kriteria } \\
\hline $0,80<\mathrm{r}_{11}$ & Reliabilitas sangat tinggi \\
$0,60<\mathrm{r}_{11}<0,80$ & Reliabilitas tinggi \\
$0,40<\mathrm{r}_{11}<0,60$ & Reliabilitas sedang \\
$0,20<\mathrm{r}_{11}<0,40$ & Reliabilitas rendah \\
$\mathrm{r}_{11}<0,20$ & Reliabilitas sangat rendah \\
& (tidak reliable) \\
\hline
\end{tabular}


c. Uji Normalitas

Uji normalitas bertujuan untuk menguji data hasil penelitian berdistribusi normal atau tidak. Uji normalitas dalam penelitian ini menggunakan uji Liliefors dengan bantuan program MS Excel, dengan taraf signifikansi $(\alpha)$ $=0,05$ dan jumlah sampel kelas eksperimen sebanyak 25 siswa. Dari table 5 dapat disimpulkan bahwa nilai hasil pretest kelas eksperimen berdistribusi normal. Syarat data berdistribusi normal yaitu jika Lhitung $<$ Ltabel.

Hasil uji normalitas pretest pada kelas eksperimen dapat dilihat dari nilai Lhitung dan Ltabel pada tabel berikut:

Tabel 5. Hasil uji normalitas kelas eksperimen

\begin{tabular}{ccc}
\hline Data & Pretest & Kesimpulan \\
\hline $\mathrm{N}$ & 25 & Lhitung $<$ Ltabel \\
Lhitung & 0,15 & $\begin{array}{c}\text { Data } \\
\text { berdistribusi }\end{array}$ \\
& & normal \\
\hline
\end{tabular}

\section{d. Uji Hipotesis}

Analisis korelasi yang merupakan analisis hubungan antara dua variabel atau lebih, yang digunakan dalam penelitian ini adalah korelasi Pearson Product Moment dengan menggunakan bantuan program Microsoft Excel 2010. Analisis ini bertujuan untuk mengetahui besarnya derajat hubungan antara variabel $X$, yaitu prestasi belajar siswa materi larutan elektrolit dan nonelektrolit dengan menggunakan model pembelajaran langsung dan variabel $\mathrm{Y}$, yaitu sikap siswa.

Soal pretest dan posttes yang berisi 10 butir soal dan angket sikap siswa terhadap metode pembelajaran yang berisi 20 butir menunjukkan nilai korelasi untuk model pembelajaran langsung sebesar 0,602. Untuk mengetahui nilai tersebut signifikan atau tidak, maka $r$ hitung dibandingkan dengan $r$ tabel pada taraf signifikan $\alpha=0,05$ dari tabel $\mathrm{r}$ dengan $\mathrm{dk} 25-2=$ 23, diperoleh sebesar 0,41. Dengan nilai tersebut menunjukkan bahwa $\mathrm{r}$ hitung $>\mathrm{r}$ tabel pada model pembelajaran direct instruction diperoleh $0,602>0,41$ sehingga terdapat hubungan antara sikap dan hasil belajar siswa.

Berdasarkan hasil hitung uji hipotesis hubungan antara sikap siswa dengan menerapkan model pembelajaran langsung terhadap prestasi belajar siswa kelas X IPA diperoleh $r_{x y}=0,602$. Nilai $\mathrm{KP}=36,00 \%$. Hasil koefisien yang bernilai positif ini menunjukkan bahwa semakin baik sikap siswa terhadap pembelajaran kimia dengan menerapkan model langsung maka akan semakin tinggi prestasi belajar yang diperoleh siswa. Untuk memberikan penafsiran terhadap koefisien korelasi yang ditemukan tersebut maka diukur koefisien determinasinya yang besarnya adalah kuadrat dari koefisien korelasi $\left(\mathrm{r}^{2}\right)$, yaitu $\mathrm{r}=$ koefisien determinasinya $=r^{2}=0,602^{2}=0,36$. Hal ini berarti besarnya hubungan sikap siswa dengan menerapkan model pembelajaran langsung terhadap prestasi belajar siswa pada materi larutan elektrolit dan nonelketrolit adalah sebesar $36,00 \%$ sedangkan $64,00 \%$ sisanya dipengaruhi oleh faktor lain yang tidak diteliti. Berdasarkan tabel interpretasi terhadap koefisien korelasi maka didapatkan tingkat hubungan yang kuat antara sikap dan prestasi belajar siswa.

Selanjutnya dilakukan uji signifikan nilai korelasi $r$ ke dalam nilai $\mathrm{t}$ kriteria dengan derajat kebebasan 23. Didapatkan thitung $=3,62$ sementara tabel pada taraf signifikan $\alpha=0,05=$ 2,06, Karena thitung $>$ tabel maka berada pada daerah penolakan $\mathrm{H}_{0}$ sehingga dapat disimpulkan bahwa terdapat hubungan signifikan antara sikap siswa terhadap prestasi belajar siswa pada materi larutan elektrolit dan nonelektrolit.

\section{Pembahasan}

Penelitian ini dilaksanakan pada kelas $X$ IPA tahun ajaran 2018/2019 di SMA N 2 Tondano. Tujuan dari penelitian ini yaitu untuk mengetahui hubungan antara model pembelajaran langsung dengan sikap siswa dan prestasi belajar siswa pada materi larutan elektrolit dan nonelektrolit. Sebelum proses pembelajaran dilakukan terlebih dahulu tes sikap (angket) dan tes prestasi belajar (pretest) tujuannya untuk mengukur kemampuan awal siswa mengenai sikap siswa terhadap kimia dan pembelajaran yang akan diberikan. Selanjutnya pembelajaran dilakukan menggunakan model pembelajaran langsung dan dilakukan tes akhir yaitu tes sikap dan tes prestasi (posttest). Berdasarkan tabel 6 menunjukkan bahwa sikap siswa terhadap kimia sebelum mengguanakan model pembelajaran langsung, diperoleh skor 
pada kategori sangat baik yaitu $0 \%$ (0 siswa), kategori baik yaitu 7 siswa $(28,00 \%)$, kategori cukup baik yaitu sebanyak 6 siswa $(24,00 \%)$, kategori kurang baik yaitu 8 siswa $(32,00 \%)$ dan kategori sangat kurang baik yaitu 4 siswa ( $16,00 \%)$. Sehingga dapat disimpulkan bahwa sikap siswa sebelum menerapkan model pembelajaran langsung tergolong pada sikap kurang baik. Hasil uji distribusi frekuensi tentang sikap siswa terhadap pembelajaran kimia dapat dilihat pada tabel berikut ini:

Tabel 6. Distribusi frekuensi sikap siswa sebelum menggunakan model pembelajaran langsung

\begin{tabular}{|c|c|c|c|c|}
\hline No & $\begin{array}{c}\text { Rentang } \\
\text { Nilai }\end{array}$ & $\begin{array}{c}\text { Kateg } \\
\text { ori }\end{array}$ & $\begin{array}{c}\text { Frek } \\
\text { uens } \\
\text { i }\end{array}$ & $\begin{array}{l}\text { Prese } \\
\text { ntase }\end{array}$ \\
\hline 1. & $80<X$ & $\begin{array}{c}\text { Sangat } \\
\text { Baik }\end{array}$ & 0 & $0 \%$ \\
\hline 2. & $\begin{array}{l}66,67<x \\
\leq 80\end{array}$ & Baik & 7 & $28 \%$ \\
\hline 3. & $\begin{array}{l}53,33<x \\
<66,67\end{array}$ & $\begin{array}{c}\text { Cukup } \\
\text { Baik }\end{array}$ & 6 & $24 \%$ \\
\hline 4. & $\begin{array}{l}40<x \\
\leq 66,67\end{array}$ & $\begin{array}{l}\text { Kuran } \\
\text { g Baik } \\
\text { Sangat }\end{array}$ & 8 & $32 \%$ \\
\hline \multirow[t]{2}{*}{5.} & & $\begin{array}{l}\text { Kuran } \\
\text { g Baik }\end{array}$ & 4 & $16 \%$ \\
\hline & Jumlah & & 25 & $100 \%$ \\
\hline
\end{tabular}

Berdasarkan tabel 7 diperoleh hasil sikap siswa terhadap pembelajaran kimia yaitu sebanyak 21 siswa (84\%) memiliki sikap sangat baik dan kategori baik yaitu sebanyak 4 siswa $(16,00 \%)$ dengan skor tertinggi siswa sebesar 98,00 . Sehingga dapat disimpulkan bahwa meningkatnya sikap belajar siswa terhadap kimia setelah menggunakan model pembelajaran langsung.

Tabel 7. Distribusi frekuensi sikap siswa sesudah menggunakan model pembelajaran langsung

\begin{tabular}{ccccc}
$\mathbf{N}$ & $\begin{array}{c}\text { Renta } \\
\text { ng } \\
\mathbf{N}\end{array}$ & $\begin{array}{c}\text { Katego } \\
\text { Nilai }\end{array}$ & $\begin{array}{c}\text { Frekuen } \\
\text { si }\end{array}$ & $\begin{array}{c}\text { Presenta } \\
\text { se }\end{array}$ \\
\hline & & Sangat \\
1. & $80<X$ & $\begin{array}{c}\text { Baik } \\
\text { Baik }\end{array}$ & 21 & $84 \%$ \\
\hline
\end{tabular}

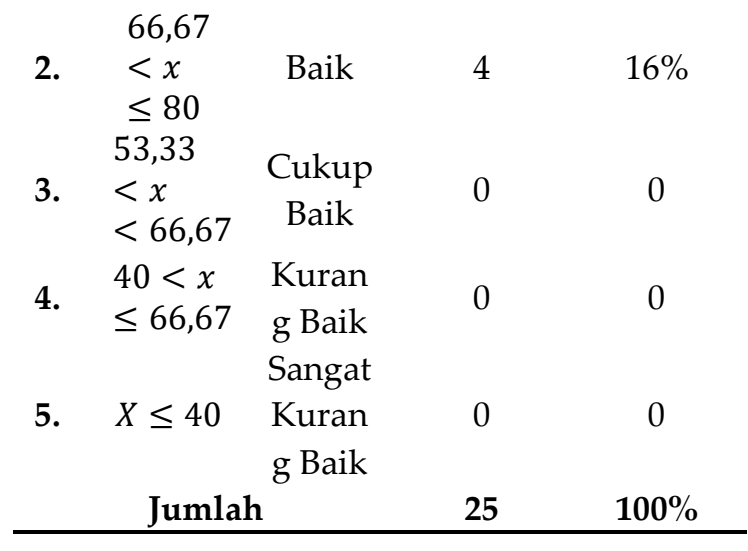

Distribusi frekuensi sikap positif dan negatif siswa sebelum dan sesudah menggunakan model pembelajaran langsung menunjukkan bahwa frekuensi data sikap siswa sebelum mengunakan model pembelajaran langsung yang tergolong negatif sebanyak 4 siswa $(16 \%)$, yang termasuk dalam kategori sedang sebanyak 14 siswa (56\%), dan yang termasuk dalam kategori positif sebanyak 7 siswa (28\%). Berdasarkan data hasil uji frekuensi sikap dapat diketahui bahwa siswa memiliki sikap positif yaitu 25 siswa $(100 \%)$ terhadap pembelajaran kimia, sehingga dapat disimpulkan bahwa sikap negatif siswa berkurang setelah dilakukan model pembelajaran langsung sehingga siswa mempunyai sikap yang positif tentang pembelajaran kimia dan mengikuti pembelajaran dengan baik.

Siswa yang memiliki sikap positif berdampak penting untuk dapat memahami pelajaran di kelas, karena sikap siswa dapat menurun seiring berjalannya waktu. Sikap siswa yang positif terhadap mata pelajaran kimia terlihat pada sikap siswa yang awalnya belum sepenuhnya menyukai pembelajaran kimia terdorong untuk menyukainya dengan guru memberikan model pembelajaran yang menyenangkan bagi siswa. Sikap positif siswa terhadap mata pelajran kimia membuktikan bahwa prestasi siswa dalam belajar kimia menjadi lebih baik. Diketahui bahwa sikap positif siswa SMA Negeri 2 Tondano khususnya kelas X IPA mengalami peningkatan setelah dilakukan Model pembelajaran langsung, hal ini berdasarkan data yang diperoleh dari angket sikap siswa yang diberikan sebelum dan sesudah perlakuan di kelas. 
Tabel 8. Presentase Selisih Prestasi Belajar dan Angket Sikap Siswa

\begin{tabular}{cccc}
\hline No & Nama & $\begin{array}{c}\text { Presentase } \\
\text { Selisih } \\
\text { Prestasi } \\
\text { Belajar }\end{array}$ & $\begin{array}{c}\text { Presentase } \\
\text { Selisih } \\
\text { Angket } \\
\text { Sikap }\end{array}$ \\
\hline 1. & M.M & $67 \%$ & $24 \%$ \\
2. & J.M & $43 \%$ & $53 \%$ \\
3. & R.D & $74 \%$ & $26 \%$ \\
4. & B.K & $76 \%$ & $31 \%$ \\
5. & N.K & $73 \%$ & $52 \%$ \\
6. & J.H & $54 \%$ & $63 \%$ \\
7. & S.M & $83 \%$ & $49 \%$ \\
8. & C.T & $96 \%$ & $31 \%$ \\
9. & S.K & $94 \%$ & $57 \%$ \\
10. & J.T & $70 \%$ & $35 \%$ \\
11. & S.K & $64 \%$ & $59 \%$ \\
12. & R.J & $45 \%$ & $35 \%$ \\
13. & G.M & $60 \%$ & $42 \%$ \\
14. & M.T & $50 \%$ & $45 \%$ \\
15. & Y.T & $28 \%$ & $28 \%$ \\
16. & G.W & $32 \%$ & $49 \%$ \\
17. & G.L & $38 \%$ & $31 \%$ \\
18. & S.S & $38 \%$ & $27 \%$ \\
19. & F.S & $24 \%$ & $33 \%$ \\
20. & A.M & $38 \%$ & $36 \%$ \\
21. & W.K & $43 \%$ & $55 \%$ \\
22. & A.R & $37 \%$ & $37 \%$ \\
23. & K.T & $32 \%$ & $57 \%$ \\
24. & D.T & $67 \%$ & $63 \%$ \\
25 & L.G & $43 \%$ & $61 \%$ \\
\hline & & & \\
\hline
\end{tabular}

Data hasil uji pada tabel 8 diatas menunjukkan bahwa presentase angket sikap siswa terhadap pembelajaran kimia dan prestasi belajar siswa materi larutan elektrolit dan nonelektrolit pada siswa kelas X IPA masing-masing mengalami kenaikan. Sebagai contoh salah satu siswa sikap sebelum menggunakan model pembelajaran langsung 79,00 dan sesudah menggunakan model pembelajaran langsung meningkat menjadi 98,00 dengan prestase kenaikan yang diperoleh meningkat menjadi 67,00\%, kenaikan presentase selisih sikap didasarkan pada kondisi awal yaitu sebelum perlakuan dan kondisi akhir yaitu sesudah perlakuan. Pada prestasi belajar siswa skor pretest 48,00 dan skor posttest 80,00 dengan presentase kenaikannya menjadi $24 \%$, hal ini dikuti oleh seluruh siswa yang mengalami presentase kenaikan pada sikap dan prestasi belajar. Hal ini membuktikan bahwa sikap terhadap mata pelajaran kimia berpengaruh terhadap kenaikan prestasi siswa dalam belajar.

Sikap positif siswa terhadap mata pelajaran kimia telah membuktikan bahwa prestasi siswa menjadi lebih baik dalam belajar kimia. Prestasi dan sikap dapat ditingkatkan oleh siswa dengan menggunakan model pembelajaran kimia yang menyenangkan, sehingga semakin tinggi sikap siswa maka prestasi siswa juga akan meningkat. Hal ini membuktikan bahwa sikap positif terhadap kimia berkorelasi dengan prestasi belajar siswa. Dengan demikian dapat disimpulkan bahwa terdapat hubungan yang besar antara sikap siswa terhadap pembelajaran kimia dengan prestasi belajar siswa pada materi larutan elektrolit dan nonelektrolit.

Berdasarkan pengalaman yang diperoleh peneliti sewaktu mengajar dengan menerapkan model pembelajaran langsung, siswa lebih aktif dalam proses belajar mengajar terutama saat diskusi berlangsung. Hal ini dapat dibuktikan dengan antusiasme siswa dalam mengerjakan soal dan tugas-tugas yang diberikan anggota kelompoknya serta tanggung jawab siswa dalam menyelesaikan tugas dan laporan tepat pada waktunya, hal ini membuktikan bahwa adanya sikap positif siswa dalam pembelajaran kimia. Berdasarkan data hasil penelitian yang diuraikan diatas dapat disimpulkan bahwa sikap dan prestasi belajar siswa meningkat dengan menerapkan model pembelajaran langsung sehingga terdapat hubungan yang signifikan antara penerapan sikap positif siswa dalam peningkatan prestasi belajar pada materi larutan elektrolit dan nonelektrolit kelas X IPA di SMA Negeri 2 Tondano.

\section{Kesimpulan}

Hasil pengujian model pembelajaran dan uji korelasi Pearson Product Moment $\left(\mathrm{r}_{\mathrm{x} y}=0,602\right)$ menunjukkan tingkat hubungan yang kuat antara prestasi belajar dan sikap siswa yaitu pada interval 0,60-0,79. Selanjutnya dilakukakn uji sikap positif siswa sebelum dan sesudah perlakuan diperoleh hasil bahwa sikap positif siswa tentang pembelajaran kimia meningkat. Berdasarkan hasil presentase selisih diatas menunjukkan bahwa sikap siswa dan prestasi 
belajar siswa mengalami kenaikan atau peningkatan. Hasil uji signifikan nilai korelasi $r$ kedalam nilai $\mathrm{t}$ (thitung $=3,62>\mathrm{t}_{\text {tabel }}=2,06$ ) yang dilakukan menunjukkan terdapat peningkatan prestasi belajar siswa yang menggunakan model pembelajaran langsung. Berdasarkan hasil penelitian tersebut, maka dapat disimpulkan bahwa terdapat hubungan model pembelajaran langsung terhadap sikap dan prestasi belajar siswa SMA, dimana terdapat peningkatan sikap postif siswa dalam pembelajaran kimia dan prestasi belajar siswa pada materi larutan elektrolit dan nonelektrolit.

\section{Daftar Pustaka}

1. Organization for Economic Cooperation and Development. Excellence and Equity in Education, PISA: OECD Publishing, Paris, PISA 2015 Results 2016, Volume I.

2. Rajakorpi. A. dalam Kausa P. (2018) Lowachieving students' attitudes towards learning chemistry and chemistry teaching methods, department of chemistry education: university of helsinki, finland, Chem. Educ. Res. Pract. 1999. 16.

3. George R. Measuring Change in Students' Attitudes Toward Science Over Time: An Application of Latent Variable Growth Modeling, J. Sci. Educ. and Technol. 2000. 213-225.

4. Hall T. Differentiated instruction, National Center on Accessing the General Curriculum (NCAC),retrieved from. 2002.

5. Desy E. A., Peterson S. A. \& Brockman V. dalam Kausa P. (2018) Low-achieving students' attitudes towards learning chemistry and chemistry teaching methods, department of chemistry education: university of helsinki, finland, Chem. Educ. Res. Pract. 2011.

6. Arends, R.I. Learning to Teach 5th Edition. USA: The McGraw-Hill Companies, Inc 2001.

7. Sugiyono. (2014). Metode Penelitian Kuantitatif Kualitatif Dan RED. Bandung: Alfabeta 